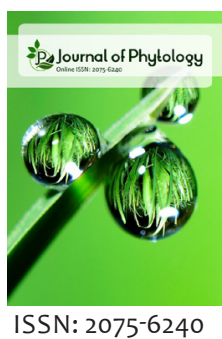

ISSN: $2075-6240$

\title{
Effect of seed invigoration with inorganic nanoparticles on seed yield in chilli (Capsicum annum)
}

\author{
Riya Mary Mathew, Dijee Bastian, Rose Mary Francies, Anita Cherian. K, \\ K. Raja, Milu Herbert \\ Department of Seed Science and Technology, College of Horticulture (Kerala Agricultural University) \\ Vellanikkara-680656, Kerala, India
}

Received: October 22, 2020

Revised: February 4, 2021

Accepted: February 5, 2021

Published: February 26, 2021

*Corresponding Author:

Riya Mary Mathew,

E-mail: riyateena@gmail.com

\begin{abstract}
An experiment was conducted to study the effect of seed invigoration with inorganic nanoparticles on plant growth and seed yield of chilli. Seed invigoration with nano particles of $\mathrm{ZnO}$ and $\mathrm{TiO}_{2}$ was found to be beneficial in improving yield and yield attributes. Seed treatment with nano $\mathrm{ZnO} @ 1300 \mathrm{mg} \mathrm{kg}^{-1}$ of seed and nano $\mathrm{TiO}_{2} @ 900 \mathrm{mg} \mathrm{kg}^{-1}$ exhibited increased plant height, fruits per plant, fruit length, fruit yield, number of seeds per fruit and seed yield.
\end{abstract}

KEYWORDS: Seed invigoration, nanoparticle, seed quality

\section{INTRODUCTION}

The production of high-quality seeds is one of the most strategic resources for higher yield. Seed quality can be considered as a summation of all factors that contribute to seed performance. Seed treatments can be generally defined as, all operations that are executed on seeds after taking them from mother plant. These practices aim to improve yields by protecting from insects, diseases and ensuring uniform crop stand across a variety of environmental conditions and soil types. Since the treatments are applied to seeds, the land area which is exposed to active ingredients is reduced. The rate of chemicals applied per hectare is less thus the cost of cultivation can be decreased (Sharma, 2015). Seed invigoration with nanoparticles is a relatively novel technology successful in many crops. The size of nanoparticles being $100 \mathrm{~nm}$ (or less than $100 \mathrm{~nm}$ ) in one or more dimensions, have unique properties and they have the potential to improve plant metabolism. The positive effects of nanoparticles include enhanced germination per cent, length of root and shoot and vegetative biomass of seedlings in many crop plants (Agarwal \& Rathore, 2014). Over the years, use of metal based nanoparticles like Gold, Titanium, Copper and Zinc are increasing exponentially because of their enhanced biological activities and physiochemical properties.

Many studies suggests that zinc oxide and titanium dioxide nanoparticles increase plant growth and development. Zinc oxide nanoparticles increases biomass accumulation, maintains membrane integrity and helps in the functioning of several enzymes (Burman. et al., 2013). Nano Zn application ameliorates rice growth as it releases nutrients slowly and gradually during critical growth stages (Raj \& Subramanian, 2014). Seed dressing using $\mathrm{ZnO}$ increases number of pods/plant, shelling percentage and pod yield in peanut (Manjumdar et al., 2001). Similarly, nano $\mathrm{TiO}_{2}$ also plays a key role in absorption of inorganic nutrients and breakdown of organic substances. It also helps to remove oxygen free radicles and thus increases photosynthetic rate (Khot et al., 2012). It stimulates Ribulose 1, 5-bisphosphate carboxylase (Rubisco) activity, thereby increases photosynthesis and thus increases plant growth and development (Yang et al., 2006). Hence, the study was formulated to assess the effect of seed treatment with nano grades of $\mathrm{ZnO}$ and $\mathrm{TiO}_{2}$ on field performance and seed yield in chilli.

\section{MATERIALS AND METHODS}

The study was conducted in the Department of Seed Science and Technology, College of Horticulture, Kerala Agricultural University, Vellanikkara during May 2019. This area is located $22.25 \mathrm{~m}$ above mean sea level and its co-ordinates lies between $10.5452^{\circ} \mathrm{N}$ and $76.2740{ }^{\circ} \mathrm{E}$ and the region is characterized by hot and humid climatic conditions.

Chilli seeds of variety Anugraha were dry dressed with nano grade $\mathrm{ZnO}$ and $\mathrm{TiO}_{2}$. The seeds along with the treatments were taken in a screw capped glass bottles and was shaken 
Table 1: Influence of nano grade $\mathrm{ZnO}$ and $\mathrm{TiO}_{2}$ on yield attributes in chilli

\begin{tabular}{|c|c|c|c|c|c|c|c|}
\hline Treatment & Plant height $(\mathrm{cm})$ & Fruits/plant (Nos.) & Fruit length $(\mathrm{cm})$ & Fruit weight (g) & Fruit yield (g) & Seeds/fruit (Nos.) & Seed yield/plant (g) \\
\hline Control & 60.33 & 85.33 & 6.43 & 2.30 & 195.5 & 50.33 & 17.18 \\
\hline n Zn0@500 & 62.00 & 90.00 & 6.90 & 2.86 & 255.00 & 54.66 & 24.62 \\
\hline n Zn0@900 & 66.00 & 88.00 & 6.80 & 2.80 & 246.33 & 58.66 & 23.22 \\
\hline nZn0@1300 & 67.30 & 122.00 & 7.40 & 3.46 & 422.70 & 61.33 & 41.14 \\
\hline nTi0_@500 & 65.80 & 93.00 & 7.23 & 2.56 & 238.70 & 52.33 & 24.32 \\
\hline nTi0_@900 & 66.33 & 117.66 & 7.30 & 3.30 & 388.30 & 59.00 & 38.17 \\
\hline nTi0_@1300 & 64.10 & 114.66 & 7.00 & 3.33 & 382.13 & 59.00 & 37.20 \\
\hline
\end{tabular}

gently 5 times for $3 \mathrm{~min}$ at an interval of 3 hrs. Untreated seeds served as control. The experiment was conducted in a Randomized block design. The treatments included, control; nano $\mathrm{ZnO}-500 \mathrm{mg} \mathrm{kg}^{-1}$, nano $\mathrm{ZnO}-900 \mathrm{mg} \mathrm{kg}^{-1}$, nano $\mathrm{ZnO}-$ $1300 \mathrm{mg} \mathrm{kg}^{-1}$, nano $\mathrm{TiO}_{2}-500 \mathrm{mg} \mathrm{kg}^{-1}$, nano $\mathrm{TiO}_{2}-900 \mathrm{mg} \mathrm{kg}^{-1}$ nano $\mathrm{TiO}_{2}-1300 \mathrm{mg} \mathrm{kg}^{-1}$. The twenty day old seedlings raised in the nursery were transplanted to main field. The experimental crop was raised as per Package of practices recommendations of Kerala Agricultural University.

Plant height was measured at 120 days after transplanting from ground level to the tip of the main stem from five representative plants, randomly selected from each plot. Total number of fruits harvested per plant was recorded. The fruit length was measured from distal end to proximal length using meter scale in randomly selected ten fruits. Fruits collected from five plants were weighed using weighing balance and yield was expressed in grams. The fruits per plant, number of seeds per fruit and seed yield per plant were also recorded.

\section{RESULTS AND DISCUSSION}

The influence of seed invigoration with nano grade Zinc Oxide and Titanium dioxide on yield attributes in chilli (Capsicum annum) is presented in Table 1 . The nano particle seed invigoration treatments performed significantly higher over the control. Among the treatments, nano ZnO@1300 mg kg-1 of seed recorded the highest plant height $(67.3 \mathrm{~cm})$, fruits per plant $(122)$, fruit length $(7.40 \mathrm{~cm})$, fruit weight $(3.46 \mathrm{~g})$, fruit yield $(422.70 \mathrm{~g})$, number of seeds per fruit (62) and seed yield $(41.14 \mathrm{~g})$. In maize by using nano $\mathrm{ZnO}$ at $400 \mathrm{ppm}$ obtained highly significant results for yield, plant height, cob length and number of grains per cob when compared to control (Subbaiah, 2014).

Similarly, Raliya et al., (2015) reported that nano ZnO recorded an increase in plant height by $24.5 \%$ and Poornima and Koti, (2019) noticed a significant increase in ear head length of sorghum at $500 \mathrm{ppm}(19.33 \mathrm{~cm})$ which was followed by 1000 ppm $(19 \mathrm{~cm})$. In pepper, García-López et al., (2018) recorded that $\mathrm{ZnO}$ nanoparticles @ $1000 \mathrm{mg} \mathrm{L}^{-1}$ produced more fruits per plant (64) over control. Nanoparticle treatments with $\mathrm{ZnO}$ @ 1000 ppm recorded highest fruit weight in carrot (Elizabath et al., 2017). Khanm et al., (2017) and Sadak and Bakry, (2020) noticed a significant increase in fruit yield and seed yield respectively, when treated with different doses of nano $\mathrm{ZnO}$.

When Chickpea seeds were treated with nano $\mathrm{ZnO}$, an increment in IAA levels was observed in roots which in turn increased plant growth (Avinash et al., 2010). Agronomic efficiency of $\mathrm{Zn}$ treatments are influenced by particle size. When particle size is reduced, number of particles per unit weight is increased and thus surface area is also increased (Mortvedt, 1992). Nano particles helps in slow release of nutrients to plants and makes them available to nanoscale plant pores and therefore result in efficient nutrient use, increased plant growth and yield (Suppan, 2013).

In case of $\mathrm{TiO}_{2}$ seed treatments, nano $\mathrm{TiO}_{2} @ 900 \mathrm{mg} \mathrm{kg}{ }^{1}$ recorded highest plant height $(66.33 \mathrm{~cm})$, fruits per plant (118), fruit length $(7.30 \mathrm{~cm})$, fruit yield $(388.30 \mathrm{~g})$, number of seeds per fruit (59) and seed yield (38.17 g). Nano $\mathrm{TiO}_{2} @$ $1300 \mathrm{mg} \mathrm{kg}^{1}$ recorded highest fruit weight (3.33g) and number of seeds per fruit (59).

An increase in yield and yield promoting traits was observed by Debnath et al., (2020) in rice when treated with nano $\mathrm{TiO}_{2}$ at 500, 1000 and $2000 \mathrm{mg} \mathrm{kg}^{-1}$. According to Jaberzadeh et al., (2013), nano $\mathrm{TiO}_{2}$ at $50 \mathrm{ppm}$ recorded an increase in panicle length by $3.2 \%$ and at $0.02 \%$ recorded highest fruit weight. Similarly, Rezaei et al., (2015) reported that treatments with nano $\mathrm{TiO}_{2}$ at $0.05 \%$ recorded highest seed yield of $2416.16 \mathrm{~kg} \mathrm{ha}^{-1}$ in soyabean and Owolade and Ogunleti, (2008) noticed that application of titanium on cowpea at $125 \mathrm{ml} \mathrm{ha}^{-1}$ increased number of seeds per pod. Enhancement in plant growth and yield might be due to the action of titanium in several cellular mechanisms.

Nanoparticles interact with the living cells at molecular level. They act on plant metabolism by regulating genes, interferes with oxidative process or by providing micronutrients. According to Poornima and Koti, (2019), the reason for increased performance may be due to the increased uptake and translocation efficiency of nano particles. Zinc is essential for pollen function, chlorophyll production, germination and fertilization. Increased germination per cent in seeds treated with nano- $\mathrm{TiO}_{2}$ could be the generation of hydroxide and superoxide anions that increased intake of oxygen and water needed for quick germination and as a result it enhances plant growth and thus yield.

\section{CONCLUSION}

Nanotechnology is an emerging discipline with novel applications in agriculture. The most commonly used and widely applied types of nano particles are Zinc and Titanium. The nanoparticle treatments at higher concentration performed 
better than at lower concentrations. Nanoparticles of ZnO@ $1300 \mathrm{mg} \mathrm{kg}^{-1}$ of seed and nano $\mathrm{TiO}_{2} @ 900 \mathrm{mg} \mathrm{kg}^{-1}$ recorded superior results throughout the experiment. The results indicated that dry dressing with zinc oxide and titanium dioxide nanoparticles in chilli is effective in improving field performance and yield in chilli.

\section{REFERENCES}

Agarwal, S., \& Rathore, P. (2014). Nanotechnology pros and cons to agriculture: A review. International Journal of Current Microbiology and Applied Sciences 3(3), 43-55. https://doi.org/10.13140/2.1.1648.1926

Avinash, C. P., Sharda, S. S., \& Raghavendra, S. Y. (2010). Application of $\mathrm{ZnO}$ nanoparticles in influencing the growth rate of Cicer arietinum. Journal of Experimental Nanoscience, 5(6), 488-497. https://doi. org/10.1080/17458081003649648

Burman, U., Saini, M., \& Kumar, P. (2013). Effect of zinc oxide nanoparticles on growth and antioxidant system of chickpea seedlings. Toxicological and Environmental Chemistry, 95(4), 605-612. https://doi.org/10.108 0/02772248.2013.803796

Debnath, K., Das, A., Das, B., \& Karfoma, J. (2020). $\mathrm{TiO}_{2}$ nanoparticles enhancing germination, growth and yield of rice. International Research Journal of Pure and Applied Chemistry, 21(6), 25-30. https:// doi.org/10.9734/irjpac/2020/v21i630173

Elizabath, A., Bahadur, V., Misra, P., Prasad, V. M., \& Thomas, T. (2017). Effect of different concentrations of iron oxide and zinc oxide nanoparticles on growth and yield of carrot (Daucus carota L.). Journal of Pharmacognosy and Phytochemistry, 6(4), 1266-1269.

García-López, J. I., Zavala-García, F., Olivares-Sáenz, E., Lira-Saldívar, R. H., Díaz Barriga-Castro, E., Ruiz-Torres, N. A., Ramos-Cortez, E., VázquezAlvarado, R., \& Niño-Medina, G. (2018). Zinc oxide nanoparticles boosts phenolic compounds and antioxidant activity of Capsicum annuum L. during Germination. Agronomy, 8(10), 215. https://doi. org/10.3390/agronomy8100215

Jaberzadeh, A., Moaveni, P., Tohidi Moghadam, H. R., \& Zahedi, H. (2013). Influence of Bulk and nanoparticles titanium foliar application on some agronomic traits, seed gluten and starch contents of wheat subjected to water deficit stress. Notulae Botanicae Horti Agrobotanici Cluj-Napoca, 41(1), 201-207. https://doi.org/10.15835/ nbha4119093

Khanm, H., Vaishnavi, B. A., Namratha, M. R., \& Shankar, A. G. (2017). Nano zinc oxide boosting growth and yield in tomato: the rise of "nano fertilizer era. International Journal of Agricultural Science and Research, 7, 197-206.
Khot, L. R., Sankaran, S., Maja, J. M., Ehsani, R., \& Schuster, E. W. (2012) Application of nanomaterial in agricultural production and protection: A review. Crop Protection, 35(C), 64-70. https://doi.org/10.1016/j. cropro.2012.01.007

Majumdar, B., Venkatesh, M. S., Lal, B., Kumar, K., \& Singh, C. S. (2001). Effect of phosphorus and zinc nutrition on groundnut in an acid hapludalf of Meghalaya. Annals of Agricultural Research New Series, $22,354-359$.

Mortvedt, J. J. 1992. Crop response to level of water -soluble zinc in granular zinc fertilizers. Fertilizer Research, 33, 249-255.

Owolade, O. F., \& Ogunleti, D. O. (2008). Effects of titanium dioxide on the diseases, development and yield of edible cowpea. Journal of Plant Protection Research, 48(3), 329-335. https://doi.org/10.2478/ v10045-008-0042-5

Poornima, R., \& Koti, R. V. (2019). Effect of nano zinc oxide on growth, yield and grain zinc content of sorghum (Sorghum bicolor). Journal of Pharmacognosy and Phytochemistry, 8(4), 727-731

Raj, Y. M., \& Subramanian, K.S. (2014). Fabrication of zinc nano fertilizer on growth parameter of rice. Trends in Biosciences, 7(17), 2564-2565.

Raliya, R., Nair, R., Chavalmane, S., Wei-Ning, W., \& Biswas, P. (2015). Mechanistic evaluation of translocation and physiological impact of titanium dioxide and zinc oxide nanoparticles on the tomato (Solanum lycopersicum L.) plant. Metal/omics, 7, 1584-1594. https:// doi.org/10.1039/C5MT00168D

Rezaei, I. F., Moaveni, P., \& Mozafari, H. (2015). Effect of different concentrations and time of nano $\mathrm{TiO}_{2}$ spraying on quantitative and qualitative yield of soybean (Glycine max L.) at Shahr-e-Qods. Biological Forum, 7(1), 957-964.

Sadak, M. S., \& Bakry, B. A. (2020). Zinc-oxide and nano ZnO oxide effects on growth, some biochemical aspects, yield quantity, and quality of flax (Linum uitatissimum L.) in absence and presence of compost under sandy soil. Bulletin of the National Research Centre, 44, 98. https://doi.org/10.1186/s42269-020-00348-2

Sharma, K. Singh, U. Sharma, P., Kumar, A. \& Sharma, L. (2015). Seed treatments for sustainable agriculture-A review. Journal of Applied and Natural Science, 7(1), 521-539. https://doi.org/10.31018/jans. v7i1.641

Subbaiah, L. V. (2014). Effect of nanoscale zinc oxide particles on the yield and yield attributes of maize. M.Sc. Dissertation. Acharya N. G. Ranga Agricultural University, Guntur, India.

Suppan, S. (2013). Nanomaterials in Soil: Our Future Food Chain? (pp. 17). Institute for Agriculture and Trade Policy, Minnesota, United States.

Yang, F., Hong, F., You, W., Liu, C., Gao, F., Wu, C., \& Yang, P. (2006). Influence of nano anatase $\mathrm{TiO} 2$ on the nitrogen metabolism of growing spinach. Biological Trace Element Research, 110, 179-190. https://doi.org/10.1385/BTER:110:2:179 